\title{
A PLEBE HETEROGÊNEA DA INDEPENDÊNCIA: ARMAS E REBELDIAS NO CEARÁ (1817-1824)
}

Tyrone Apollo Pontes Cândido $2 ; 3$

\section{Resumo}

Este artigo visa mostrar como uma plebe heterogênea, composta por povos indígenas, brancos pobres, negros e mestiços, livres e escravos, envolveu-se ativamente nos principais movimentos que marcaram as lutas da independência no Ceará. Observar a participação dessas camadas subalternas de sertanejos nos conflitos armados, por vezes sujeitados a recrutamentos forçados, outras se engajando voluntariamente nas tropas oficiais ou rebeldes, possibilita entender como suas experiências como soldados, fugitivos dos recrutamentos ou desertores, proporcionaram a articulação de causas comuns em nome da liberdade, forjando outros sentidos da independência.

\section{Palavras-chave}

Plebe heterogênea - recrutamento - Independência - Ceará.

\section{THE HETEROGENEOUS PLEBS OF INDEPENDENCE: ARMIES AND REBELLIONS IN CEARÁ (1817-1824)}

\section{Abstract}

This article aims to show how a heterogeneous plebs got involved in the main movements of independence in Ceará. That plebs was composed by indigenous peoples, poor white, black and mixed-race persons, free and enslaved. Observing the participation of these subaltern habitants of the sertões in the armed conflicts, as voluntary or forced soldiers of official or rebel troops, fugitives of recruitments or deserters, allow us articulating common causes by liberty, forging other meanings of independence.

\section{Keywords}

Heterogeneous plebs - recruitment - Independence - Ceará.

${ }^{1}$ Este artigo é parte de uma pesquisa apoiada com bolsa de produtividade da Funcap.

${ }^{2}$ Universidade Estadual do Ceará - Quixadá - Ceará - Brasil.

${ }^{3}$ Professor do Curso de História e do Mestrado Interdisciplinar em História e Letras da Faculdade de Educação, Ciências e Letras do Sertão Central - Feclesc, Uece, e do Programa de Pós-Graduação de História da Universidade Federal do Ceará. 


\section{Uma plebe heterogênea}

Era comum, durante as décadas que precederam a independência, que agentes coloniais desqualificassem a maior parte da população do Ceará como composta por pessoas ignorantes e criminosas, uma "gente da pior espécie". Era como pensava, já em 1787, o ouvidor Manoel de Avelar Barbelo, ao considerar que "metade dos habitantes desta comarca são vadios sem ofício, ou vagabundos por natureza”. Opinião semelhante era sustentada pelo naturalista João da Silva Feijó que, em 1814, se referiu à "diminuta e desfalecida população" do Ceará como sendo "pela maior parte de péssima qualidade". Quanto ao ouvidor João Antônio Rodrigues de Carvalho, em Memória, datada de 1816, registrou que entre os maiores males do Ceará estavam: a "preguiça, o prejuízo de não servir homem forro, ainda que seja preto, a facilidade de se manter de furto de gados, a frequência dos crimes de morte..."

Segundo João da Silva Feijó, esse caráter reprovável da população cearense podia ser explicado pela constituição racial de sua maioria: "uns são índios originais do país, entes em si mesmos ineptos para se felicitarem ou para fazerem a felicidade dos outros", "outros são provenientes destes com os negros, cuja raça constitui o maior número dela, conhecidos com a vil denominação de cabras", outros ainda "são nascidos dos mesmos índios com os brancos (...), verdadeiros mamelucos". Em meio a tantos nativos, cabras, mamelucos, os "brancos oriundos de Portugal" constituíam uma parcela minoritária, ainda que privilegiada, da população.

Isso parecia preocupar sobremaneira o aristocrático Feijó. Em sua dedicação por revelar as potencialidades materiais da capitania para fazer a grandeza do Império lusitano, a maior parte de seus habitantes era representada como um incômodo empecilho, quando não como inimigos declarados. João da Silva Feijó atribuía à "liberalidade" com a qual a gente de cor habitava os vastos sertões a fonte de todo o mal: opinava que a abundância de raízes e batatas, a infinidade de frutas silvestres e a profusão de recursos de caça e pesca que os povos do sertão possuíam eram fatores que os tornavam "muito preguiçosos e indolentes, com particularidade os índios, cabras e mamelucos que são em extremo vadios, dissolutos nos costumes e cheios de vícios"5.

Todas essas considerações a respeito de vícios, vadiagem, crimes e indolência relacionadas ao caráter das populações sertanejas diziam respeito aos projetos de controle e civilização sobre a capitania do Ceará durante as décadas que precederam as lutas que marcaram a emancipação política brasileira. Tributário do entreposto pernambucano, seu território figurava na época como uma zona fronteiriça, com extensas fazendas de criação, seca caatinga, população rarefeita e dispersa, inexpressivo comércio e vida urbana apenas elementar. Na verdade, a capitania chegava àquele início do século XIX sem uma cidade a concentrar negócios e instituições oficiais. É mesmo curiosa a impressão que a rusticidade local causou no viajante inglês Henry Koster, quando foi recebido, em 1810, em Fortaleza, pelo governador Luiz Barba Alardo de Menezes: "O palácio era o único edifício assoalhado em toda a Vila. Parecia-me estranho ser recebido por um dos primeiros oficiais da província, numa sala apenas tijolada, com paredes caiadas"6.

Nesse cenário desolador, sob a perspectiva dos agentes metropolitanos, formou-se uma sociedade com características diferenciadas daquelas das zonas açucareiras, com seu pungente comércio exportador, grandes lavouras monocultoras e concentração de africanos escravizados. O que mais havia nos sertões cearenses, em contraste, era a criação extensiva de gado que abastecia de carnes e couros as regiões vizinhas, especialmente Pernambuco. Os engenhos que por ali se encontravam (na realidade, engenhocas, por suas pequenas dimensões e capacidade produtiva) não fabricavam açúcar em quantidade para a exportação, mas, sim, cachaça e rapadura, basicamente produtos voltados

\footnotetext{
${ }^{4}$ Representação do ouvidor do Ceará, Manoel de Avelar Barbelo, em 3 de fevereiro de 1787, a rainha, sobre a situação do Ceará e apresentando um projeto para o desenvolvimento da capitania. In: PINHEIRO, Francisco José. Documentos para a história colonial, especialmente a indígena no Ceará (1690-1825). Fortaleza: Fundação Ana Luna, 2011. p. 204. FEIJÓ, João da Silva. Memória sobre a capitania do Ceará e outros trabalhos, ed. fac-similar. Fortaleza: Fundação Waldemar Alcântara, 1997. p. 22. PAULET, Antônio José da Silva. Descrição geográfica abreviada da capitania do Ceará. In: Documentação primordial sobre a capitania autônoma do Ceará, $2^{\mathrm{a}}$ ed. fac-similar de separatas da Revista do Instituto do Ceará. Fortaleza: Fundação Waldermar Alcântara, 1997. p. 13. A autoria provável deste documento, atribuído originalmente ao engenheiro Silva Paulet, é apontada por Guilherme Studart como sendo do então ouvidor-mor João Antônio Rodrigues de Carvalho.
}

${ }^{5}$ FEIJÓ, João da Silva. Op. Cit., p. 22. Grifos do próprio autor.

${ }^{6}$ KOSTER, Henry. Viagens ao Nordeste do Brasil, 12 ed. Rio-São Paulo-Fortaleza: ABC Editora, 2003. p. 188. 
para o consumo local. Aracati e Granja, nos extremos do litoral, prosperaram em função de suas charqueadas, mas chegavam ao final do século XVIII num movimento econômico de franco declínio para o que concorreram rigorosas secas (1777-1778 e 1791-1793) ${ }^{7}$.

A ausência de grandes investimentos produtivos favoreceu o estabelecimento de um campesinato relativamente autônomo pelos sertões. Vilas foram instituídas ao longo do século XVIII pelo governo metropolitano, visando tornar mais presente o domínio ultramarino no vasto território sertanejo. No entanto, muitos povoados surgiriam a partir da reunião de comunidades de pequenos agricultores, ocasionais prestadores de serviços, unidos em função do pequeno comércio, da proteção de ataques externos, da liturgia católica e das atividades mutualistas, como aquelas próprias da fabricação da farinha ou da debulha do feijão ${ }^{8}$.

Mesmo após mais de dois séculos de ataques às nações indígenas, a população nativa do Ceará ainda era bastante expressiva no início dos Oitocentos. Das 16 vilas existentes na capitania, cinco eram vilas de índios, abrigando milhares de pessoas em cada uma delas. A maior era a vila Viçosa Real, na serra da Ibiapaba, com mais de 6.500 índios contabilizados pelo Mapa de habitantes da capitania do Ceará Grande (1808) ${ }^{9}$. Mas, além desses índios concentrados em aldeamentos, havia um incontável contingente vivendo pelas matas, evitando o contato com os brancos.

Africanos e seus descendentes, componentes de uma população negra, se faziam presentes nas diversas regiões da capitania, eram comprados como escravos em centros como Recife e São Luiz, trazidos para trabalharem nos engenhos ou prestarem serviços em fazendas de criação. A atividade doméstica era outra função comum desses cativos. Quando se descobriu o ouro em Lavras da Mangabeira, no sul do Ceará, para ali se deslocaram exploradores vindos de Minas Gerais, trazendo consigo "escravos já experientes neste trabalho". Conta João da Silva Feijó que, além de perfurarem minas, esses mineiros faiscavam pelos riachos em tempos de chuva, quando havia água para as baetações, "empregando seus escravos a jornal de pataca, no que alguns desses mais diligentes se forraram". Devem-se considerar também aqueles que procuravam o Ceará quando escapavam de senhores de outras capitanias e quando uma parte desses fugitivos era capturada e reescravizada, arrematada em leilões públicos ${ }^{10}$.

Essa diversificada população cresceu rapidamente no curso das décadas do último estágio da experiência colonial. Entre 1776 e 1808, a população cearense dobrou de tamanho: de 61.408 (3,9\% do total do país) passou para $125.764(6,1 \%)$, posicionando-se à frente do Rio Grande do Norte e da Paraíba (49.391 e 79.424, respectivamente) que, assim como o Ceará, eram capitanias anexas a Pernambuco até o fim do século XVIII. Possivelmente, esse incremento estava relacionado ao forte crescimento do tráfico de africanos para o país, verificado especialmente desde a década de 1790. Porém, uma característica é expressiva nessa formação social: assim como em Pernambuco, no Ceará havia um número muito maior de pessoas livres de cor do que de escravos ${ }^{11}$.

Na última metade do século XVIII foi quando se deu mais intensamente o mestiçamento de grande parte dessa crescente população do Ceará. Para evitar o constante assédio de particulares e oficiais da Coroa portuguesa, índios abandonavam os aldeamentos, misturando-se às populações de brancos e negros. Uma parte desses novos mestiços acabava sendo agregada em unidades rurais, exercendo funções como vaqueiros e agricultores, numa complexa rede de deveres e proteção, sob o

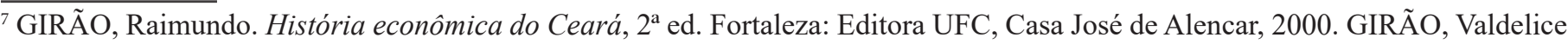
Carneiro. As oficinas ou charqueadas no Ceará. Fortaleza: Secretaria de Cultura e Desporto, 1984.

${ }^{8}$ Cf. JUCÁ NETO, Clóvis Ramiro. Primórdios da urbanização no Ceará. Fortaleza: Edições UFC; Editora Banco do Nordeste do Brasil, 2012. Sobre a formação do campesinato cf. PALACIOS, Guillermo. Campesinato e escravidão: uma proposta de periodização para a história dos cultivadores pobres livres no Nordeste oriental do Brasil: 1700-1875. In: WELCH, Clifford Andrew et al. Camponeses brasileiros: leituras e interpretações clássicas. São Paulo: Editora Unesp; Brasília, DF: Núcleo de Estudos Agrários e Desenvolvimento Rural, 2009. p. 145-180.

${ }^{9}$ MENEZES, Luís Barba Alardo de. Memória sobre a capitania do Ceará. Revista do Instituto Histórico e Geográfico Brasileiro, Rio de Janeiro, 1871. tomo 34, n. 42, $1^{a}$ parte, p. 273. Sobre as vilas de índios no Ceará cf. SILVA, Isabelle Braz Peixoto da. Vilas de índios no Ceará Grande. Dinâmicas locais sob o Diretório Pombalino. Campinas: Pontes Editores, 2005.

${ }^{10}$ FEIJÓ, João da Silva. Op. Cit., p. 368. Cf. Apreensão de escravos Viçosa 1817-1823 (livro 4) e Apreensões de escravos Sobral 1817 (livro 5). Governo da Capitania, Arquivo Público do Estado do Ceará (Apec, doravante).

${ }^{11}$ ALDEN, Dauril. O período final do Brasil colônia: 1750-1808. In: BETHEL, Leslie (org.). História da América Latina. São Paulo: Edusp, 1999. vol. II: América Latina colonial, p. 528-540. 
comando de poderosos proprietários, para os quais também se dedicavam ao manejo das armas, visto como necessário num cenário de violências. Por outro lado, muitos mergulhavam na extensa caatinga, compondo comunidades de nativos, negros alforriados, caboclos, escravos fugitivos.

O predomínio de condição livre dessa plebe heterogênea vivendo nos sertões do Ceará era visto como problemático pelos portugueses e seus descendentes mais diretos, particularmente por aqueles que desejavam usufruir dessa crescente população como mão de obra colocada a seu serviço. As comunidades indígenas lidavam com as tentativas de se fazer das vilas onde viviam fontes de trabalhadores baratos ou mesmo cativos. Brancos recorriam às aldeias para negociarem vantajosos contratos de prestação de serviços, quase nunca cumpridos regularmente pelos contratantes. $\mathrm{Na}$ verdade, essa era tida como uma via de acesso a uma mão de obra ilegalmente escravizada, como denunciaram incisivamente os índios da serra da Ibiapaba em requerimento redigido em 1814, em que refizeram um histórico de irregularidades cometidas por diversos diretores da vila Viçosa que se sucederam na administração dos índios, praticando toda sorte de negociatas que implicavam em usurpações de terra, coerção ao trabalho, salários não pagos, exploração de crianças, cobrança de tributos indevidos... ${ }^{12}$.

Verifica-se assim que, ainda que de maioria livre, as classes subalternas do Ceará travavam, durante as décadas da passagem do século XVIII ao XIX, uma acirrada luta pela liberdade. Henry Koster notaria, nesse sentido, a grande repugnância que os indígenas locais tinham por chamarem de "senhor" aos que contratavam seus serviços:

Um indígena nunca está disposto a chamar o patrão, que o haja alugado, por senhor, embora de uso comum dos brancos entre si quando falam, e por todos os homens livres da região. (...) A repugnância do uso do vocábulo senhor pode ter começado nos imediatos descendentes dos indígenas escravos e se haja perpetuado essa repugnância na tradição. Recusam dar por cortesia o que outrora lhes seria exigido pela lei ${ }^{13}$.

Fora dos aldeamentos, outras situações de coerção motivavam a luta pela liberdade. Com a certeza de que os sertões do Ceará estavam infestados de "homens facinorosos, vadios e matadores", autoridades esforçavam-se por perseguir os que não aceitassem trabalhar sob o mando dos homens brancos. O ouvidor Carvalho chegou ao ponto de julgar a simples prática de se plantar melancias, melões e jerimuns nos terrenos de vazantes dos rios como um subterfúgio do povo para "entreter ociosos que não buscam trabalho regular". Um edital de 1804, criado pelo governador João Carlos Augusto d'Oeynhausen, visava pôr fim "a ilimitada liberdade com que certa classe de gente" desprezava as leis do Império lusitano, adotando "vida errante e vagabunda" e tornando-se, com isso, "inúteis" e um "mau exemplo". Para tanto, obrigava a todos que circulassem pelos sertões do Ceará a apresentarem passaportes autenticados por juízes ordinários ou coronéis de milícia, sob pena de serem presos e "conservados como vadios", podendo ser empregados em serviços de limpeza nas vilas enquanto estivessem reclusos. Se trouxessem "armas proibidas", uma pena ainda mais severa lhes seria imposta: a execução de trabalhos forçados até a oportunidade de sua expulsão da capitania ${ }^{14}$.

Uma política persecutória recaía, assim, sobre as populações mestiças e pobres do Ceará, especialmente sobre aqueles classificados como "cabras", considerados como os mais perigosos entre os "vadios" e "criminosos". Nos últimos anos do regime colonial, a precariedade da liberdade evidenciavase, dessa maneira, na suspeição sobre a maioria dos que eram identificados como "gente de cor" ou os que com eles andavam ${ }^{15}$. Quando, no início do século XIX, aspirações liberais atiçaram os sentimentos

\footnotetext{
${ }^{12}$ XAVIER, Maico Oliveira. "Cabolullos são os brancos": dinâmicas das relações socioculturais dos índios do termo da vila Viçosa Real (século XIX). Fortaleza: Secult, 2012. p. 148-194.

${ }^{13}$ KOSTER, Henry. Op. Cit., p. 178. Grifo nosso.

${ }^{14}$ PAULET, Antônio José da Silva. Op. Cit., p. 9. Edital de 28 de janeiro de 1804. In. STUDART, barão de. Datas e fatos para a história do Ceará. Fortaleza: Fundação Waldemar Alcântara, 2001. p. 463-466.

${ }^{15}$ Sobre as condições da "gente de cor" na última metade do século XVIII ver LARA, Silvia Hunold. No jogo das cores: liberdade e racialização das relações sociais na América portuguesa setecentista. In: XAVIER, Regina Célia Lima (org.). Escravidão e liberdade: temas, problemas e perspectivas de análise. São Paulo: Alameda, 2010. p. 69-93. Cf. IRFFI, Ana Sara Ribeiro Parente Cortez. $O$ cabra do Cariri cearense: a invenção de um conceito oitocentista. Tese (Doutorado em História Social), Universidade Federal do Ceará, Fortaleza, 2015.
} 
dos que se lançaram contra o domínio colonial em crise, dividindo as elites brancas em violentos confrontos armados, a uma plebe heterogênea de índios, brancos pobres, cabras, mamelucos, negros libertos e mesmo escravos, que há tempos combatia por sua própria liberdade, seriam dadas armas e munições. Nas ocasiões das batalhas, por diversas vezes aquela gente encontraria meios de se voltar contra seus tradicionais antagonistas.

\section{O outro lado da independência}

Este artigo trata da participação das camadas subalternas da sociedade cearense nos principais episódios que marcaram as lutas travadas durante os anos de constituição da independência brasileira que, no caso do Ceará, teve início com a chamada Revolução de 1817, seguindo até o declínio da Confederação do Equador em 1824. Apesar da historiografia majoritariamente estabelecer o processo de emancipação brasileiro entre os anos de 1820 e 1822 - ou seja, desde a convocação da assembleia constituinte em Portugal (em consequência da revolução liberal do Porto) até o reconhecimento do poder imperial autônomo (centrado no Rio de Janeiro, em torno da autoridade de d. Pedro I) -, sabe-se que, observada pelas circunstâncias das províncias do Norte que orbitavam em torno de Pernambuco como seu principal centro político, uma outra temporalidade histórica pode ser estabelecida ${ }^{16}$.

Mesmo concordando com as objeções dos historiadores que, na nossa atualidade, contestam a visão teleológica que enxergava no 7 de setembro o marco de uma aspiração nacional prévia, sabemos que diversas linhas de continuidade podem ser estabelecidas entre a insurreição de 1817 e a definitiva adesão das províncias do Norte nos meses finais de $1824^{17}$. Sobretudo, muitos dos personagens que atuaram em 1817 seriam os mesmos que, entre 1820 e 1821, assumiriam posição de destaque nos conflitos relacionados às eleições para as cortes de Lisboa. Seguindo-se as eleições para a constituinte no Rio de Janeiro em 1822-1823, estes personagens encampariam a expedição em auxílio à "causa brasileira" no Piauí e Maranhão em 1823 e, enfim, travariam lutas durante a tentativa de ruptura com o regime político já independente por meio da adesão à Confederação do Equador em 1824 .

Por todos esses anos, as principais disputas opondo "brasileiros" e "portugueses", republicanos e imperiais, federalistas e unitários nas diferentes fases da luta deram-se por meio do uso da força armada em movimentos e batalhas em que se entrechocavam tropas encabeçadas pelos chefes das famílias de maior influência em suas respectivas localidades ${ }^{18}$. O Ceará figura entre aqueles casos em que a adesão ao novo império não se deu pela persuasão ou negociação pacífica, mas, sim, por meio da imposição armada e violenta.

Essa característica do processo emancipatório local esclarece algumas das razões pelas quais grandes parcelas da população cearense foram convocadas para a participação direta nos episódios representados como decisivos a futuro da causa nacional. Muitos indígenas dos diferentes aldeamentos do Ceará foram, desse modo, mobilizados para fazer a repressão aos rebeldes de 1817, ao lado de diversos corpos de ordenança de perfil étnico heterogêneo. Do outro lado das trincheiras, também um número expressivo de cabras, caboclos, pardos, livres e escravos pegaram em armas. Com a retomada das exaltações liberais em reação à convocação das cortes lisboetas em 1821, novos choques voltariam

\footnotetext{
${ }^{16}$ É o que sugere MELLO, Evaldo Cabral de. A outra Independência: o federalismo pernambucano de 1817 a $1824,2^{\mathrm{a}}$ ed. São Paulo: Editora 34, 2014. Sobre 1817 cf. MOTA, Carlos Guilherme. Nordeste 1817: estruturas e argumentos. São Paulo: Perspectiva, 1972. Sobre a Confederação do Equador cf. ARAÚJO, Maria do Carmo R. A participação do Ceará na Confederação do Equador. In: SOUZA, Simone (coord.). História do Ceará. Fortaleza: Universidade Federal do Ceará/ Fundação Demócrito Rocha/Stylus Comunicações, 1989. p. 139-148.

${ }^{17}$ Como sustentam István Jancsó e João Paulo Pimenta, "hoje é assente que não se deve tomar a declaração da vontade de emancipação política como equivalente da constituição do Estado nacional brasileiro, assim como o é o reconhecimento de que o nexo entre a emergência desse Estado com a da nação em cujo nome ele foi instituído é uma das questões mais controversas da nossa historiografia”. JANCSÓ, István; PIMENTA, João Paulo Garrido. Peças de um mosaico (ou apontamentos para o estudo da emergência da identidade nacional brasileira). In: MOTA, Carlos Guilherme (org.). Viagem incompleta. A experiência brasileira (1500-2000). Formação: histórias, $2^{a}$ ed. São Paulo: Senac, 2000. p. 127-175. Cf. diversos pontos de vista presentes em: JANCSÓ, István (org.). Independência: história e historiografia. São Paulo: Hucitec, 2005 e MALERBA, Jurandir (org.). A Independência brasileira: novas dimensões. Rio de Janeiro: FGV, 2006.

${ }^{18}$ No Ceará, de modo semelhante ao que se deu na Paraíba e em outras províncias, as relações entre redes familiares e poder político foram fundamentais nos processos da independência. Cf. MARIANO, Serioja Rodrigues Cordeiro. Gente opulenta e boa linhagem: família, política e relações de poder na Paraíba (1817-1824). 286 f. Tese (Doutorado em História), Programa de Pós-Graduação em História, Universidade Federal de Pernambuco, Recife, 2005. 
a se dar no interior do território cearense, com indígenas e cabras por vezes promovendo protestos autônomos e expressando seus próprios projetos na cena política que se convencionava ser domínio exclusivo das elites. Quando, em 1823, a junta provisória da província atendeu ao pedido de socorro por parte daqueles que, no Piauí, combatiam a resistência do comandante das armas em aderir ao novo regime, milhares de homens de todo o sertão cearense formariam um poderoso exército. E, finalmente, novas batalhas seriam travadas em 1824, constituindo-se corpos armados daquela composição heterogênea popular de indígenas, mestiços e negros ${ }^{19}$.

A incorporação popular nas tropas atuantes nas lutas desse período resultou em complexos desdobramentos sociais. Aquele tempo foi marcado por recrutamentos em massa, muitas vezes forçados, pelo disciplinamento de tropas com métodos violentos, pela vigilância tentando conter as deserções frequentes, pela perseguição a esses desertores, pelos castigos físicos e as prisões sofridos pelos soldados recalcitrantes, pela fome e falta nos pagamentos durante as duras jornadas movimentando-se pelas quentes veredas na caatinga. Além disso, por onde iam, os corpos armados apenavam criadores e agricultores, cobrando doações e empréstimos de gêneros alimentícios e animais de tração, quando não simplesmente promoviam a franca pilhagem. A intensidade com que se deu a militarização da população cearense, majoritariamente sertaneja, abalaria as relações de poder estabelecidas, pois o antagonismo das camadas subalternas da sociedade tendeu a crescer com as condições opressivas dos tempos de guerra, sobretudo quando uma parcela considerável do povo se encontrava armada.

Isso tudo per se revela que a participação popular nas lutas da independência não se restringia a mera adesão aos projetos políticos formulados pelas frações das elites em disputa. Pelo contrário, observa-se aqui como debates e conflitos pareceram encorajar os setores não privilegiados da sociedade a defender, na arena pública, projetos políticos independentes, de acordo com aspirações sociais próprias. Ao discutir a participação desses sujeitos nos eventos que contribuíram para a emancipação brasileira e formação do novo império, este artigo insere-se no campo de análise de uma historiografia que se volta para o entendimento acerca de "outras independências" que devem ser consideradas ${ }^{20}$.

Porém, no mais das vezes, as abordagens sobre a presença popular nas lutas pela independência (e nas revoltas a elas conectadas) enfocam preferencialmente as razões de adesão dos diferentes indivíduos, grupos e etnias aos projetos políticos constituídos ${ }^{21}$. Neste artigo, diferentemente, a atenção principal se volta para a atuação conjunta de grupos e etnias subalternas agregados não em torno de um entendimento político comum (pois muitos, nesse sentido, encontravam-se em campos opostos), porém pelas experiências compartilhadas enquanto um setor social visado pelos recrutamentos e sujeito a todas as formas de opressão associadas. Privilegiando o estudo acerca das ações (agency) desses sujeitos históricos poderemos constituir uma linha de interpretação capaz de entender melhor as motivações que orientavam sua atuação.

O presente artigo busca, assim, se inserir numa perspectiva de "história vista de baixo", tendo por inspiração as perspectivas teóricas orientadas pelos chamados estudos subalternos (subaltern studies), impulsionados por historiadores indianos como Ranajit Guha e Gayatri Chakravorty Spivak que apreendem entre os subalternos da sociedade conotações políticas e intelectuais opostas às dominantes, sustentadas pelas elites ${ }^{22}$. Nosso enfoque recai, portanto, preferencialmente sobre os atores populares

\footnotetext{
${ }^{19}$ Pesquisas anteriores discutiram a participação dos grupos locais na província cearense no período abordado no presente artigo. Destacam-se duas delas: FELIX, Keile Socorro Leite. "Espíritos inflamados": a construção do estado nacional brasileiro e os projetos políticos no Ceará (1817-1840). 231 f. Dissertação (Mestrado em História Social), Programa de Pós-Graduação em História, Universidade Federal do Ceará, Fortaleza, 2010. COSTA, João Paulo Peixoto. Na lei e na guerra: políticas indígenas e indigenistas no Ceará (1798-1845). 369 f. Tese (Doutorado em História), Programa de Pós-Graduação em História, Universidade de Campinas, Campinas, 2016.

${ }^{20}$ Ver, entre outros exemplos, RIBEIRO, Gladys Sabina. O desejo da liberdade e a participação de homens livres pobres e "de cor" na Independência do Brasil. Caderno Cedes, Campinas, vol. 22, n. 58, p. 21-45, dez. 2002. REIS, João José. O jogo duro do dois de julho: o "partido negro" na independência da Bahia. In: REIS, J.; SILVA, Eduardo. Negociação e conflito: a resistência negra no Brasil escravista. São Paulo: Companhia das Letras, 1989. p. 79-98. CARVALHO, Marcus Joaquim Maciel de. O outro lado da independência: quilombolas, negros e pardos em Pernambuco (1817-23). Luso-Brazilian Review, vol. 43, n. 1, 2006. BERNARDES, Denis Antônio de Mendonça. A gente ínfima do povo e outras gentes na Confederação do Equador. In: DANTAS, Mônica Duarte (org.). Revoltas, motins, revoluções: homens livres pobres e libertos no Brasil do século XIX. São Paulo: Alameda, 2011. p. 131-166.

${ }^{21}$ Cf. SILVA, Luiz Geraldo. Negros patriotas: raça e identidade social na formação do Estado nação (Pernambuco, 1770-1830) e KRAAY, Hendrik. Identidade racial na política, Bahia, 1790-1840: o caso dos henriques. In: JANCSÓ, István. Brasil: a formação do estado e da nação. São Paulo: Hucitec, Ed. Unijuí, Fapesp, 2003.

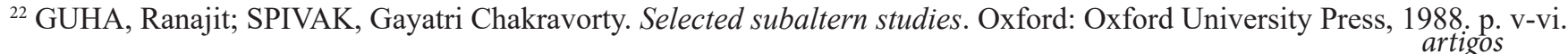


que, de alguma forma, eram subordinados em termos de classe, etnia, gênero e profissão, considerando suas articulações coletivas comuns ou, por vezes, antagônicas. Mas como todo processo de dominação é sempre uma relação de mão dupla, envolvendo tanto dominantes quanto dominados, os grupos de elite também serão considerados na relação recíproca que estabelecem com as parcelas dominadas.

Tomando por base uma análise dos ofícios trocados entre autoridades civis e militares entre os anos de 1817 e 1824, com apoio de registros de cronistas e historiadores do século XIX ${ }^{23}$, as páginas que seguem buscam, num primeiro momento, apresentar a mobilização das tropas que atuaram nas principais campanhas do período para, em seguida, analisar como conflitos ocorridos em torno dos recrutamentos, disciplinamento das tropas, deserções e punições originaram revoltas e outras formas de resistência popular.

\section{Mobilizações}

Em 1817, ao chegarem as primeiras notícias sobre os acontecimentos de 6 de março em Recife, o governo da capitania tratou de ordenar a todos os corpos de soldados do Ceará que ficassem de prontidão, garantindo a defesa do território ante uma esperada invasão de agentes revolucionários. Em 30 de março, o governador Manoel Inácio de Sampaio expediu destacamentos para toda a costa, a fim de prevenir o desembarque de emissários de Pernambuco e, no mesmo dia, enviou a Aracati um contingente numeroso de soldados sob as ordens do coronel Alexandre José Leite de Chaves e Melo para a partir dali promover a fortificação das fronteiras com Rio Grande do Norte e Paraíba. Dessas primeiras medidas resultaria a prisão do ouvidor João Antônio Rodrigues de Carvalho, cujas ideias liberais fizeram levantar sobre si suspeitas de conspiração com o movimento de Recife, bem como a captura de uma jangada na enseada do Retiro Grande, a oito léguas de Aracati, trazendo adeptos republicanos com fardamentos e papéis de conteúdo sedicioso. Provenientes da vila de Fortaleza, esses primeiros destacamentos eram formados por aproximadamente 300 soldados pagos das guarnições de infantaria e artilharia aquarteladas na capital. A esses se somariam praças das tropas auxiliares de Aracati ${ }^{24}$.

Toda a vigilância não pôde impedir, no entanto, a chegada do então seminarista José Martiniano de Alencar que partira de Olinda pelos caminhos do sertão para provocar o levantamento rebelde na vila do Crato, no sul da capitania. Alencar, fazendo discurso após a missa do dia 3 de maio, inflamou a população cratense que recebeu a adesão das tropas comandadas pelo capitão-mor José Pereira Filgueiras. À proclamação da República no Crato um dia depois, seguiu-se a mobilização de forças para marchar sobre o Icó, importante centro comercial às margens do rio Jaguaribe, onde residiam muitos portugueses fiéis ao Império luso-brasileiro. O capitão-mor Filgueiras partiu então para sua propriedade, o engenho São Paulo, onde tratou de reunir homens para a expedição do Icó. Contava com a chegada de reforços vindos de Souza, Pombal e Piancó, vilas do sertão da Paraíba, além de Martins e Apodi, do Rio Grande do Norte. Ao mesmo tempo, outras lideranças insurgentes armavam seus próprios regimentos.

José Pereira Filgueiras, porém, logo seria convencido dos perigos que a revolta suscitava, agindo, a partir de então, em favor das forças governistas. Homem forte do poder militar no Cariri cearense, Filgueiras seria o fiel da balança da Revolução de 1817 no Ceará. Ao passar para o lado do governo, praticamente desbaratou os planos de expansão da revolta pela capitania. Desistiu, assim, do ataque a Icó e uniu seus cerca de 500 soldados aos do coronel de cavalaria Leandro Bezerra Monteiro, zeloso defensor dos interesses da monarquia portuguesa, num ataque contra a vila do Crato, na manhã do dia 11 de maio ${ }^{25}$.

As notícias advindas do sul da capitania intensificariam os cuidados do governador Sampaio que

\footnotetext{
${ }^{23}$ Em sua maior parte, a documentação aqui abordada encontra-se no Apec, nos fundos do governo da capitania e governo da província do Ceará. Alguns desses conjuntos documentais foram reproduzidos em publicações, tais como a Revista do Instituto Histórico e Geográfico Brasileiro, Revista Trimestral do Instituto do Ceará e outras coleções cujas referências encontram-se em notas ao longo do artigo. O artigo também tem por base as narrativas presentes em THEBERGE, Pedro. Esboço histórico sobre a província do Ceará, ed. fac-similar. Fortaleza: Fundação Waldemar Alcântara, 2001. tomo II, e SANTOS, João Brígido dos. Ceará (homens e fatos). Fortaleza: Edições Demócrito Rocha, 2001. (Col. Clássicos Cearenses)

${ }^{24}$ Ofícios de 28 de abril, 6, 19 e 22 de maio de 1817. Ofícios dirigidos aos militares desta capitania do Ceará (caixa 11, livro 37). Governo da Capitania: Correspondência expedida, Apec. Cf. STUDART FILHO, Carlos. A revolução de 1817 no Ceará. Revista do Instituto do Ceará, p. 5-99, 1960, ano LXXIV.
}

${ }^{25}$ THEBERGE, Pedro. Op. cit., p. 24-27. 
ordenou o deslocamento de novas tropas em direção à ribeira do Jaguaribe, onde se situavam as vilas de Aracati, São Bernardo e Icó, consideradas centros mais vulneráveis às ações rebeldes. Trezentos índios dos aldeamentos de Soure, Messejana e Arronches, além de outras centenas de soldados das tropas de milícias de Granja, Sobral, São João do Príncipe e Baturité, seguiram para se colocar sob as ordens do coronel Alexandre José Leite, comandante das fronteiras e inspetor das milícias do Jaguaribe. Em ofício ao sargento-mor José Agostinho Pinheiro, diretor dos aldeamentos de índios de Soure e Arronches, localizados há poucos quilômetros de Fortaleza, o governador Sampaio assim ordenava:

(...) faça reunir nesta capital 200 índios das vilas de Arronches e Soure que V. M. é Diretor para que, depois de bem municiados, juntamente com outros 100 índios que aqui deve achar da vila de Messejana, formem todos um corpo de 300 homens que debaixo de suas ordens se vá reunir na vila do Icó com o corpo de soldados de linha e milícias que comanda o Coronel José Alexandre Leite de Chaves e Melo ${ }^{26}$.

Entre maio e junho de 1817, praticamente todo território cearense encontrava-se em armas. Muitos homens que não haviam partido em socorro às tropas oficiais foram recrutados na composição dos corpos de ordenança, responsáveis por substituir as tropas deslocadas na manutenção da ordem local, preservando a segurança de cadeias e quartéis.

Apesar dos limites da Revolução de 1817 no Ceará, as mobilizações de setores populares nas tropas (rebeldes ou governistas) foram intensas e massivas. Por toda a parte circularam os corpos armados, perseguindo e operando prisões, escoltando autoridades, conduzindo sediciosos, preparando expedições, atacando vilas e povoados. Entre os revolucionários, seriam capturados tanto os líderes das elites quanto seus anônimos liderados. As glórias da vitória, assim como as amargas derrotas, foram compartilhadas por oficiais de alta patente, mas também pelos soldados rasos dos destacamentos. A gente comum do sertão atendeu aos chamados rebeldes, empunhou armas pela causa republicana, mas também resolveu desertar quando percebeu seus comandantes acuados pelas forças oficiais. Da parte do governo, lutaram com distinção o regimento de pardos do Icó e as tropas de índios que avançaram pelas fronteiras, subjugando vilas na Paraíba e no Rio Grande do Norte, vasculhando a caatinga na espreita de fugitivos.

Derrotadas as principais lideranças do movimento republicano de 1817 no Ceará, nem por isso deixou de despertar preocupações a continuada circulação de ideias, escritos e discursos de escopo liberal-exaltado pelos sertões. Daí porque, nos anos que se seguiram, prisões e movimentação de tropas continuaram o trabalho de repressão, em particular nas vilas e povoados das margens do rio Jaguaribe. Porém, mobilizações mais expressivas de regimentos armados no Ceará voltariam a ocorrer somente com o advento da revolução de $1820 \mathrm{em}$ Portugal, quando a convocação de uma assembleia constituinte faria a perspectiva do constitucionalismo reacender alguns dos ideais anteriormente plantados em $1817^{27}$.

Em 14 de abril de 1821, houve um levantamento das tropas de linha de Fortaleza, cercando o palácio do governo, onde obrigaram o governador português Francisco Alberto Rubim a jurar as bases da constituição, ameaçando depô-lo em caso de recusa. Rubim viu-se obrigado também a dobrar os soldos dos oficiais, atitude que o senado da câmara de Fortaleza julgou necessária para evitar um confronto armado ${ }^{28}$.

Nos meses seguintes, as convocações para eleição de deputados às cortes de Lisboa despertariam novas agitações e conflitos que, por vezes, revelaram a emergência de protestos das camadas inferiores da sociedade. Em vilas do Cariri (Crato, Missão Velha, Jardim), missas celebradas aos domingos e feriados foram diversas vezes interrompidas por homens armados que vociferavam contra as reformas, as eleições das juntas, os ideais liberais, que julgavam como um atentado contra o sagrado governo d'el rey e da monarquia lusitana. As ações desses plebeus armados que ficaram conhecidos pela alcunha de "cerca-igrejas" culminaram nos episódios do dia 5 de agosto, data marcada para a reunião da junta

\footnotetext{
${ }^{26}$ Ofício de 23 de maio de 1817. Registro de ofícios dos capitães mores de distrito, 1816-1817. Governo da Capitania: Correspondência expedida, Apec.

${ }^{27}$ BERBEL, Márcia Regina. A nação como artefato: deputados do Brasil nas cortes portuguesas (1821-1822). São Paulo: Hucitec, 1999.

${ }^{28}$ THEBERGE, Pedro. Op. Cit., p. 33.
} 
eleitoral do Crato proceder à nomeação de eleitores às cortes portuguesas. Segundo registrou Pedro Theberge:

Já o sacerdote convenientemente paramentado se dispunha a dar começo à cerimônia, quando os sediciosos, vulgarmente conhecidos pelo título de cerca-igrejas, se espalharam pelas ruas da Vila, gritando que se queriam subtrair de cima do altar a imagem da padroeira, N. S. da Penha, para substituí-la por uma prostituta, amásia de um dos chefes da reforma ${ }^{29}$.

Os que estavam no interior do templo procuravam fugir, em pânico, mas os cerca-igrejas trataram de impedir. Quando o sargento-mor José Vitoriano Maciel puxou sua espada para tentar, com sua autoridade, conter o tumulto, foi atacado, recebendo uma cacetada e um tiro que o deixou gravemente ferido. Somente com a intervenção enérgica de José Pereira Filgueiras pôde-se conter o furor do que Pedro Theberge qualificou de "populaça triunfante e sequiosa de sangue", que se retiraram então na direção da serra de São Pedro, onde muitos deles moravam. Retornariam dias depois para pedir perdão pelos distúrbios aos membros da câmara que lhes prometeram esquecer os acontecimentos passados. Todavia, procedeu-se a uma devassa, da qual resultou a identificação de alguns culpados que foram punidos $^{30}$. O desembargador José Raimundo Porbem Barbosa, ouvidor da comarca do Crato, diante da crise, trataria de redigir um plano para a formação de quatro novas companhias armadas "para manter a segurança pública e conter o grande número de cabras e crioulos amotinadores e perturbadores da ordem pública", como deixou registrado em documento enviado ao governador Rubim ${ }^{31}$.

Toda a sequência de acontecimentos que conduziu o Ceará à condição de nação separada do governo lusitano transcorreu sob a pressão de tropas armadas. No dia 3 de novembro de 1821, o governador Francisco Alberto Rubim foi enfim deposto quando patriotas exaltados clamaram pela intervenção dos regimentos de Fortaleza que, amotinados, percorreram as ruas da vila aos gritos de "Vivam as cortes portuguesas!" Nem por isso a escolha dos deputados para as cortes de Lisboa se daria sem resistências, pois destacamentos mobilizados no Crato e em Icó (mais fiéis aos interesses absolutistas que aos desígnios da junta de governo provisório instituída em Fortaleza) ameaçavam os eleitores com prisões e vinganças.

A libertação, nesse ínterim, dos presos de 1817 foi decisiva ao processo, tanto por ter colocado nas ruas importantes articuladores favoráveis à ruptura com Portugal quanto porque possibilitou que membros da família Alencar convencessem o capitão mor José Pereira Filgueiras a, mais uma vez, estabelecer a aliança, passando juntos a apoiar os interesses ditos patrióticos. Com o decreto de 3 de julho de 1822, pelo qual Pedro I convocava novas eleições, agora para uma assembleia constituinte brasileira, novas escaramuças surgiram pelas vilas do Ceará, com provocações de parte a parte, ocasionando perseguições, prisões, ataques, violências de toda sorte.

Em 16 de outubro de 1822, foi instaurado um governo independente na comarca do Crato, quando o corpo de eleitores se encontrava reunido em Icó. Um destacamento comandado pelo tenente Manoel Antônio Diniz, no entanto, procedeu à prisão de diversos desses eleitores. Chegando a notícia dessa reação ao Crato, a câmara daquela vila tratou de eleger José Pereira Filgueiras como membro do governo temporário e este, mobilizando suas tropas, partiu para o ataque contra as forças comandadas pelo tenente Diniz. Ao chegar a Icó no dia 26 de outubro, libertou os patriotas da prisão, enquanto os regimentos apoiadores da causa portuguesa fugiam para o centro da província, onde foram atacados e seus comandantes capturados. Quando, enfim, a câmara de Fortaleza declarou sua adesão à independência, em 24 de novembro, as forças sob a liderança de Filgueiras já preparavam seu avanço sobre a capital do Ceará ${ }^{32}$.

No tempo em que se formava a junta de governo independente em Fortaleza, chegaram, em janeiro de 1823 , as primeiras notícias da reação portuguesa no Piauí. Em 2 de novembro do ano anterior, a câmara da vila de Parnaíba havia proclamado sua adesão a d. Pedro I, fato que despertou a reação do major João José da Cunha Fidié, português contrário à independência e comandante das armas

\footnotetext{
${ }^{29}$ Ibidem, p. 34. Grifos do próprio autor.

${ }^{30}$ Ibidem, p. 35.

${ }^{31}$ Ata de 27 de agosto de 1821. Atas do Conselho Consultivo, 1821-1822. Governo da Capitania, Apec.

${ }^{32}$ THEBERGE, Pedro. Op. Cit., p. 37.
} 
do Piauí. Partindo de Oeiras, capital daquela província, marchou com um poderoso destacamento de artilharia para abafar os movimentos da Parnaíba. A população, atemorizada, abandonou aquela vila e procurou refúgio, cruzando a fronteira com o Ceará. Em Granja, situada no extremo norte do Ceará, próxima à fronteira com o Piauí, soldados cearenses e piauienses uniram-se e partiram para o confronto contra o exército de Fidié. O embate ocorreu na que ficou conhecida como a Batalha de Jenipapo, no dia 13 de março. Após confronto sangrento, quando mais de duzentos soldados quedaram mortos, afora muitos feridos e centenas de prisioneiros, as tropas do major Fidié seguiram vitoriosas.

As repercussões sobre os acontecimentos do Piauí foram intensas no Ceará. Em Fortaleza, uma junta militar, chefiada por José Pereira Filgueiras e Tristão Gonçalves Pereira de Alencar, foi designada para organizar uma forte expedição. Partiram da capital no dia 29 de março, porém não diretamente para o Piauí; a formação daquele exército seria feita com o recrutamento de sertanejos de todo o Ceará que foram aderindo (às vezes forçados) à expedição por onde ela passava: Aquiraz, Aracati, São Bernardo, Icó, Crato. Para esse último ponto deveriam convergir os corpos de milícia do grande sertão cearense ${ }^{33}$.

Mais uma vez, grupos indígenas seriam mobilizados para a luta, como os da missão de Conceição, orientados a marchar para a vila do Crato: "todos os índios que puderem seguir com seus competentes arcos e flechas". Em cada localidade por onde a expedição passava, ordens expressas eram emitidas para que oficiais tratassem de recrutar o máximo de homens capacitados para os combates. Para fazer frente ao número elevado de soldados, procedia-se igualmente à aquisição forçada de armas pelos povoados. Em ofício de 19 de abril, Filgueiras e Tristão de Alencar ordenavam, nesse sentido, que se fizessem "buscas nas casas em que lhe constar existirem armas de fogo e, havendo-as a si por uma lista de suas qualidades e donos, arme a sua tropa e os soldados que não a tiverem" ${ }^{34}$.

O recrutamento forçado, feito em larga escala, provocou uma resistência de grandes proporções, $o$ que dificultou sobremaneira a formação da expedição em auxílio ao Piauí. A aproximação da expedição fazia com que muitos aptos a se tornarem soldados abandonassem suas casas para escapar do exército. E mesmo recrutados davam um jeito de fugir das tropas, antes da marcha seguir em direção ao Crato. Nesse sentido, ao chegarem em Lavras, em 30 de abril de 1823, os chefes da expedição acusavam deserções de soldados em três companhias, orientando o tenente coronel João André Teixeira Mendes a proceder na captura dos fugitivos:

...faça toda a diligência possível para prender aos desertores Carlos José, casado nesta vila, Antonio Vieira, casado no mesmo lugar, Antonio Manoel dos Santos e João do Carmo, e seguros remetê-los em seguimento da expedição, para com seu castigo darmos um exemplo a toda a tropa ${ }^{35}$.

No Crato, a então mais populosa vila da província, e de onde esperava-se o recrutamento dos maiores contingentes de soldados, deu-se um verdadeiro levante "de homens pardos e pretos de que abundam aqueles lugares". Filgueiras e Tristão de Alencar, em ofício, informavam haver ali "mais de 2000 cabras em armas e prontos a praticar as maiores hostilidades, tendo já perpetrado roubos e dispostos a instalar um governo a seu molde". Aquele que foi qualificado como um "estado anárquico" constituiu-se em problema de grandes dimensões, a ponto de um conselho militar composto pelos "oficiais de estado maior do exército" ter sido convocado para deliberar sobre a crise. Decidiu-se então que a expedição só partiria para o Piauí após a prisão dos cabeças da sedição, medida julgada indispensável para fazer os "povos flutuantes iludidos das vilas" de Jardim, Lavras e Crato entrarem "nos seus deveres de subordinação"36.

Sobre a composição da expedição, registrou o historiador João Brígido dos Santos:

\footnotetext{
${ }^{33}$ Sessão extraordinária em 24 de janeiro de 1823. Atas do Conselho Consultivo, 1821-1822. Governo da Capitania, Apec.

${ }^{34}$ Ofícios de 12 e 19 de abril de 1823. ARARIPE, Tristão de Alencar. Expedição do Ceará em auxílio do Piauí e Maranhão. Revista do Instituto Histórico, Geográfico e Etnográfico do Brasil. Rio de Janeiro: Tipografia Universal de Laemmert, 1885. tomo XLVIII, p. $281-282$ e 303 .

${ }^{35}$ Ofício de 30 de abril de 1823. Ibidem, p. 369-370.

${ }^{36}$ Ofícios de 6 e 20 de abril e 9 de maio de 1823. Ibidem, p. 261-262 e 307.
} 
Bandos de homens do campo, mal armados, sem disciplina e mal provisionados, moveram-se de todos os pontos, comandados por oficiais que não tinham noções do serviço militar e, quando os dois chefes passaram revista a seu exército na fronteira do Piauí (Várzea da Vaca), em princípio de junho, só dispunham de uma massa informe sem organização de guerra e, à guisa de povo nômade, invadindo território inimigo ${ }^{37}$.

Essa "massa informe sem organização de guerra" - na verdade um imenso contingente de mais de 6.000 homens - faria a glória do novo Império das Américas ao derrotar as forças de Fidié em Caxias, reduto português no Maranhão, para onde o major conduzira suas tropas em fuga. Durante alguns meses, a expedição cearense ficou estacionada em Caxias, fustigando as forças inimigas, mas também praticando invasões de roçados da população local, roubando e saqueando, como muitos reclamaram. Quando um destacamento se dirigiu a São Luiz para cobrar recursos com os quais fossem pagos os soldados, rompeu-se o pacto com o governo do Maranhão, fazendo com que as tropas cearenses decidissem retornar.

A retirada dos regimentos do Ceará para o Piauí e Maranhão fez-se sentir pela crise que ali se instaurou. Grassaram pelas vilas do sertão ações de bandidos, em francos ataques, praticando roubos e assassinatos. Num ofício, alertava-se sobre as notícias de que

nossa província se acha coalhada de ciganos e que esses inimigos do sossego público, dilaceradores da honra e fazenda alheia e, réu da polícia, aproveitando-se desta ocasião em que parte dos povos saem, se preparam para saquear os lugares que sabem se acham desguardados, para o que não pouparão hostilidades e quantos insultos

lhes possa lembrar ${ }^{38}$.

Embora, aparentemente, nenhum caso do tipo tenha se confirmado, a sensação de insegurança parecia ser geral em face da ausência dos principais corpos armados do Ceará.

Em janeiro de 1824, quando as tropas expedicionárias se encontravam de volta ao Crato, Tristão de Alencar recebeu ali a notícia da dissolução da assembleia constituinte na corte. Novas mobilizações armadas tiveram lugar, dessa vez em protesto contra o que se julgava ser uma traição perpetrada por $d$. Pedro I, rompendo o pacto coordenado entre as lideranças provinciais que lutavam pela independência e almejavam maior poder de decisão sobre os rumos do novo regime. Em 9 de janeiro, a câmara de Quixeramobim, reunindo a população local, declarou decaído o monarca, clamando por um governo republicano ${ }^{39}$. Nova movimentação de tropas agora partiria em direção a Fortaleza.

Em muitas vilas do Ceará, o rompimento com o Rio de Janeiro vinha sendo discutido ante o fato consumado da dissolução da assembleia constituinte. Enquanto isso, em Fortaleza, o governo provisório estava nas mãos do oficial Francisco Félix de Carvalho Couto, comandante das tropas de linha, que havia assumido o poder da província, enquanto Tristão e Filgueiras ausentavam-se para compor a expedição do Piauí. Uma vez retornados a Fortaleza, tendo sob suas ordens um poderoso corpo de milhares de soldados, Tristão de Alencar e Filgueiras destituíram Carvalho Couto, restaurando a antiga composição do governo.

Milhares de homens armados, muitos deles orgulhosos por terem participado da libertação de Caxias, encontravam-se agora acampados no povoado indígena de Arronches, contíguo à capital cearense; e, todos os dias, novos soldados aderiam às tropas, convocados em vilas do sertão. Sua presença foi decisiva para a deposição de Pedro José da Costa Barros, oficial cearense nomeado pelo imperador Pedro I para governar o Ceará ${ }^{40}$. A partir de então, pelos meses que se seguiram, os movimentos armados visaram proteger a costa e as fronteiras de um provável ataque dirigido desde Rio de Janeiro, Bahia e o sul de Pernambuco, territórios que concentravam regimentos fieis ao imperador naquele novo momento de crise. Pernambuco, Paraíba, Rio Grande do Norte e Ceará declarariam

\footnotetext{
${ }^{37}$ SANTOS, João Brígido dos. Op. Cit., p. 47.

${ }^{38}$ Ofício de 6 de maio de 1823. ARARIPE, Tristão de Alencar. Op. Cit., p. 395-396.

${ }^{39}$ Termo da sessão da Câmara da vila de Campo Maior (Quixeramobim) a 9 de janeiro de 1824. Documentos para a história da Confederação do Equador no Ceará coligidos pelo barão de Studart. Revista do Instituto do Ceará, tomo especial, p. 355-357, 1924.

${ }^{40}$ Ofício de Tristão Gonçalves comunicando a deposição de Costa Barros, 10 de maio de 1824. Ibidem, p. 386-387. 
sua ruptura com a monarquia, formando a Confederação do Equador, cuja adesão foi aclamada em Fortaleza no dia 26 de agosto de 1824.

A república teria vida curta no Ceará, esmagada que foi pelos ataques desferidos por terra e por mar, o que provocou reviravoltas e traições de todo tipo até que os últimos líderes findassem isolados, presos e condenados ao fuzilamento. Antes disso, porém, seriam ainda intensas as movimentações de tropas e as batalhas. Tão logo instituído o novo governo republicano em Fortaleza, tratou-se da formação de uma expedição militar que deveria partir da capital cearense para Pernambuco. Sua principal motivação estava relacionada à necessidade de socorrer a causa republicana na província aliada com maiores contingentes armados. Além disso, visava a libertação do major Luiz Rodrigues Chaves que havia sido preso na Paraíba enquanto se deslocava para Recife. Ademais, quando partiu de Fortaleza no dia 3 de setembro, a expedição levava consigo os deputados eleitos no Ceará para, na capital pernambucana, decidirem as bases constitucionais da Confederação ${ }^{41}$.

A passagem da expedição por vilas como Aracati e Icó foi decisiva para a adesão das respectivas câmaras ao regime recém-instituído. Muitos membros das municipalidades, ainda que sinceramente indignados com a suspensão da assembleia constituinte e dispostos a não aceitar a imposição da nova constituição outorgada por d. Pedro I, relutavam em declarar sua adesão à Confederação, possivelmente por perceberem os perigos que aquela atitude poderia lhes trazer num cenário tão incerto. Nesse contexto de indefinições, não tardaram a surgir resistências e ataques por parte daqueles fieis ao império.

Com a aproximação das tropas vindas de Fortaleza, portugueses e imperiais de Icó deixaram a vila para organizar a resistência armada na serra do Camará e no povoado de Pereiro. Ali seriam atacados por destacamentos enviados por José Pereira Filgueiras, porém estes retornariam derrotados. Enquanto isso, na vila de Jardim, um reduto antiliberal, os representantes que haviam participado da cerimônia de adesão à Confederação do Equador foram brutalmente capturados, torturados e mortos. Pouco depois, regimentos republicanos chegaram à vila e lançaram-se contra os adversários com a mesma violência. João Brígido dos Santos, em carta enviada a Pedro Theberge, narrou assim os acontecimentos:

Foi cruel o procedimento dos republicanos com os prisioneiros. Metiam-nos em um quadrado e os espancavam a cacete até expirarem; depois arrastavam-nos pelas pernas e os atiravam dentro da matriz para serem sepultados! Foram muitos os que assim pereceram, nenhum sobreviveu ao suplício ${ }^{42}$.

Esse ataque da expedição republicana à vila de Jardim ocorreu no dia $1^{\circ}$ de outubro de 1824 . Em seguida, as forças comandadas por José Pereira Filgueiras avançaram até o Crato, onde receberiam o reforço de novos soldados, armas e mantimentos. No dia 9, partiu na frente um destacamento de batedores, composto por 200 soldados, na direção de Rio do Peixe, Paraíba. Em seguida, o grosso do exército expedicionário pôs-se em marcha, composto por tropas regulares e corpos de milícias fornecidos por diversos pontos da província. Eram mais de 2.000 homens com armas de fogo, arcos e flechas, lanças e outros armamentos.

Era visível, a essa altura, a superioridade bélica das tropas republicanas, porém, de sua parte, os imperiais também tratavam de reunir forças e não tardou para iniciarem seus ataques. No caminho que tomaram em direção a Rio do Peixe, os regimentos republicanos sofreram várias emboscadas. Não podendo enfrentar os inimigos numa abordagem frontal, os corpos imperiais faziam descargas contra os soldados republicanos, fugindo em seguida; caíam de surpresa sobre os flancos da tropa ou sobre a retaguarda, capturando e matando os retardatários ou aqueles que se apartavam do exército principal. Essas emboscadas acabaram forçando o recuo da expedição para a vila de Icó e dali até o Crato.

Os expedicionários deixavam um rastro de mortes, roubos e incêndios por onde passavam. Quando chegaram a Icó, os soldados ameaçaram amotinarem-se caso não recebessem seus pagamentos

\footnotetext{
${ }^{41}$ Decreto de 5 de outubro de 1824. Decreto que manda suspender para a Província do Ceará as formalidades do $\S 8$ do art. 179 da Constituição e cria uma Comissão Militar na mesma província. Ibidem, p. 410-411.

${ }^{42}$ SANTOS, João Brígido dos. Micellanea histórica ou coleção de diversos escriptos de J. Brígido, ed. fac-similar. Fortaleza: Fundação Waldemar Alcântara, 2009. p. 105-106. 
atrasados, o que levou Filgueiras a arrombar as portas de um comerciante português cuja loja foi completamente saqueada ${ }^{43}$.

Eram os estertores das lutas da Confederação do Equador no Ceará. Tristão de Alencar, que havia permanecido em Fortaleza, reuniu em outubro regimentos de índios, brancos e mestiços para conterem ataques por mar, esperados em Aracati. Transferiu o comando das armas para as mãos do tenente coronel Antônio Bezerra de Souza que, por sua vez, viu-se compelido a partir para a região de Uruburetama, dias depois, para ali combater imperiais que ameaçavam o governo republicano da capital. Apesar de Tristão de Alencar ter conseguido, em 17 de outubro, conquistar a vila de Aracati das mãos dos imperiais, logo recebeu a notícia da restauração consumada em Pernambuco, o que provocou grande desânimo no exército de 2.000 homens sob seu comando. Nesse momento, Fortaleza havia também capitulado, diante das ameaças da frota de lorde Cochrane. As principais vilas cearenses seguiram o exemplo da capital, procedendo a solenidades de juramento à constituição do Império. Isoladas, as tropas republicanas foram seriamente desfalcadas pela deserção em massa e os remanescentes tomaram o caminho do sertão, iniciando uma tática de resistência na forma de guerrilha. Tristão de Alencar tombaria morto em fuga na localidade de Santa Rosa, em 31 de outubro. No Crato, as forças republicanas também decidiram abandonar a resistência, fugindo em direção à vila do Exu, em território pernambucano. O capitão Filgueiras, acuado, se entregaria em meados de novembro, morrendo na prisão em território pernambucano, enquanto era transferido para o Rio de Janeiro ${ }^{44}$.

Outros conflitos ainda se dariam no ano seguinte, mobilizando os últimos corpos armados compostos por aquela gente comum que formava a maioria dos sertanejos cearenses. A essa altura, no entanto, o poder político da província já se encontrava definitivamente atrelado ao projeto de construção do Império do Brasil hegemonizado pelos representantes aliados ao monarca Pedro I.

\section{Armas e rebeldias}

A narrativa sobre as mobilizações de tropas durante os conflitos entre 1817 e 1824 apresenta a inserção das classes subalternas nos episódios mais importantes da emancipação brasileira e da formação do regime monárquico no Ceará. Evidencia também que esse processo esteve longe de poder ser caracterizado como uma conquista pacífica, sem grandes abalos sociais. Ao contrário disso, o que se pode perceber são elementos que apontam para um período de intensa militarização da população que, envolvendo variadas composições das camadas pobres de vilas e povoados, convulsionou as relações de dependência que ligavam os estratos inferiores da sociedade a autoridades, comandantes militares e proprietários rurais detentores de poder e prestígio.

A incorporação de indígenas e afrodescendentes nas corporações armadas a serviço da Coroa portuguesa remonta a tempos remotos da colonização. Em especial, as guerras travadas contra a invasão holandesa no século XVII marcam o surgimento dos regimentos formados por nativos e negros que se destacaram, primeiramente no período da resistência à invasão batava (1630-1635), em seguida nos esforços de reconquista da capitania de Pernambuco (1645-1654). Foi essa a época da criação do renomado terço dos henriques, tropa que assumiu esse nome em função de seu comandante, um negro de condição livre chamado Henrique Dias que, à frente de uma companhia composta por 36 homens forros e escravos, ofereceu seus voluntários serviços a oficiais portugueses e espanhóis. A importância que teve o terço dos henriques na expulsão dos holandeses rendeu a Henrique Dias prestígio e homenagens; os cativos de sua corporação foram alforriados e, com o fim dos conflitos contra os holandeses, o Império português decidiu manter o terço dos henriques para os combates que haveriam de ser travados dali adiante contra os chamados "inimigos internos", ou seja, nos ataques a índios hostis e quilombolas ${ }^{45}$.

\footnotetext{
${ }^{43}$ THEBERGE, Pedro. Op. Cit., p. 101.

${ }^{44}$ Ofício de 4 de novembro de 1824. Antonio José Moreira relata ao imperador as peripécias da marcha de Tristão Gonçalves contra Aracati, tomada e abandonada a vila, e expõe os serviços que prestou à causa monárquica. Documentos para a história da Confederação do Equador no Ceará coligidos pelo barão de Studart. Revista do Instituto do Ceará, tomo especial, p. 471-474, 1924. THEBERGE, Pedro. Op. Cit., p. 103.

${ }^{45}$ Cf. SILVA, Luiz Geraldo; SOUZA, Fernando Prestes de. Negros apoyos. Milicianos afrodescendientes, transición política y cambio de estatus en la era de las independencias (capitanías de São Paulo y Pernambuco, Brasil, 1790-1830). Nuevo Mundo Mundos Nuevos, Débats 2014. Disponível em: <http://journals.openedition.org/nuevomundo/67529>. Acesso em: 6 de junho de 2018.
} 
No Ceará, ao longo do século XVIII, a formação de tropas etnicamente constituídas de índios, pardos e pretos acompanhou o próprio processo de efetiva conquista da capitania contra a forte resistência das tribos hostis que ali viviam. $\mathrm{O}$ avanço sobre o interior do território verificou-se com a intensa participação guerreira de particulares e de grupos indígenas aliados que, como mostrou pesquisa de José Eudes Gomes, foi premiada com a doação de terras em sesmaria, com o apresamento indígena e a nomeação dos que assumiam a linha de chefia com postos do oficialato das novas tropas estabelecidas localmente. Afirmou Gomes que "estes fatores possibilitaram a formação de uma primeira elite colonial (...), materializada localmente pelo comando de bandos armados e pela riqueza em terras, escravos e rebanhos"46. Durante o século XVIII, a formação social da capitania cearense guardou, portanto, uma íntima relação com a instituição dos corpos militares constituídos por forte presença de não-europeus.

Homens como José Pereira Filgueiras, Francisco Alves Feitosa, Tristão Gonçalves de Alencar, Leandro Bezerra Monteiro e Francisco Xavier Torres foram exemplos desses líderes, cuja influência sobre as populações locais os qualificava a receberem patentes das autoridades lusitanas, o que apenas contribuía para fazer crescer ainda mais o rol de cabedais de que dispunham, como grandes régulos dos sertões que eram. O uso dessas ferramentas de poder, herdadas da formação do Antigo Regime nos trópicos, oferecia uma larga margem de autonomia a esses oficiais que exerceram papel importante na construção da emancipação política no Cearáa ${ }^{47}$.

O poder desses líderes militares encontrava-se em relação direta com a capacidade que deveriam demonstrar ter de reunir centenas ou milhares de homens pobres, armados, situados no outro lado do espectro social, sob seu comando. Esse controle estava longe de ser algum dado previsto na estrutura social, figurando antes como um campo aberto às contingências das disputas que antagonizavam autoridades coloniais e mandatários locais, de um lado, e a diversificada camada da gente comum sertaneja, de outro.

A própria maneira como se constituíam as forças armadas no país reproduzia essa complexa relação de poder que envolvia governo metropolitano, oficiais militares e soldados. As forças armadas eram divididas em regimentos de primeira linha, milícias e ordenanças. Apenas as tropas de primeira linha eram constituídas por soldados pagos, responsáveis por manter a segurança das capitanias, mobilizados para as frentes de batalha sempre que necessário. Sendo, em geral, numericamente insuficientes para as várias atribuições conferidas às forças armadas, aos regimentos de primeira linha costumavam serem agregadas tropas auxiliares, as milícias, recrutadas por oficiais nas vilas. Esses corpos eram formados por homens selecionados nas povoações que só ocasionalmente recebiam fardamentos, armas e pagamentos, quando convocados. As tropas de ordenança, enfim, praticamente confundiamse com a totalidade da população masculina em condições de lutar. Às ordenanças, geralmente, era entregue a responsabilidade pela manutenção da ordem local, enquanto soldados de primeira linha e milicianos encontravam-se deslocados ${ }^{48}$.

Assim sendo, apenas uma pequena parcela dos engajados nas tropas que atuaram nas lutas da independência seria de soldados regulares pagos. Na sua maioria, os corpos armados eram recrutados no seio da população civil masculina que deixaria para trás seus afazeres profissionais ao serem convocados para as batalhas. De acordo com as informações fornecidas pelo governador da capitania, Luiz Barba Alardo de Menezes, as tropas de linha (pagas) no Ceará, em 1814, restringiam-se a duas companhias, uma de infantaria e outra de artilharia, ambas aquarteladas em Fortaleza. Juntas, essas guarnições totalizavam apenas 308 soldados $^{49}$. No quadro abaixo, pode-se observar como tropas pagas (primeira linha) e não pagas (milícias e ordenanças) estavam distribuídas pelas diferentes vilas nesse mesmo ano:

\footnotetext{
${ }^{46}$ GOMES, José Eudes. As milícias d'el rey: tropas militares e poder no Ceará setecentista. Rio de Janeiro: Fundação Getúlio Vargas Editora, 2010. p. 125.

${ }^{47}$ VIEIRA Jr., Antônio Otaviano. Entre paredes e bacamarte: história da família no sertão (1780-1850). Fortaleza: Edições Demócrito Rocha/Hucitec, 2004.

${ }^{48}$ IZECKSOHN, Victor. Ordenanças, tropas de linha e auxiliares: mapeando os espaços militares luso-brasileiros. In.: FRAGOSO, João; GOUVÊA, Maria de Fátima (org.). O Brasil colonial, 1720-1821. Rio de Janeiro: Civilização Brasileira, 2014. vol. 3, p. 483-521.

${ }^{49}$ MENEZES, Luís Barba Alardo de. Op. Cit., p. 273. 


\section{Tropas militares da capitania do Ceará (1814)}

Vila

Fortaleza Nossa Senhora da Assunção

Soure

Arronches

Messejana

São José do Ribamar do Aquiraz

Montemor o Novo

Santa Cruz do Aracati

São Bernardo das Russas

Nossa Senhora da Expectação do Icó

Crato

São João do Príncipe

Vila Nova d'El Rei

Campo Maior de Quixeramobim

Vila Viçosa Real

Granja

Vila Distinta Real de Sobral

Total
Tropas

8 companhias de ordenanças

4 companhias de milícias

2 companhias de tropas de linha

3 companhias de ordenanças de índios

5 companhias de ordenanças de índios

8 companhias de ordenanças de índios

3 companhias de milícias

6 companhias de ordenanças

2 companhias de ordenanças a cavalo

8 ordenanças

3 companhias do regimento de infantaria miliciana das marinhas do Ceará e Jaguaribe

10 companhias de ordenanças

1 regimento de cavalaria miliciana das vargens do Jaguaribe e Quixeramobim (13 companhias)

12 companhias de ordenanças

1 regimento de infantaria miliciana dos homens pardos (13 companhias)

1 regimento miliciano de cavalaria ( 13 companhias)

1 regimento de cavalaria miliciana (10 companhias) e outras tantas de ordenanças

2 companhias de ordenanças

10 companhias do regimento de cavalaria miliciana da Serra dos

5 companhias de ordenanças e "algumas do regimento de cavalaria miliciana das varges do Jaguaribe"

5 companhias de ordenanças a cavalo

4 companhias de ordenanças

3 companhias do regimento de milícias do Acaraú

10 companhias de ordenanças e "outras tantas do regimento de cavalaria miliciana"

88 companhias de ordenanças

9 regimentos milicianos ( 3 de infantaria e 6 de cavalaria)

2 companhias de tropa pagas (uma de infantaria e uma de artilharia) Fonte: GOMES, José Eudes. Op. Cit., p. 265.

Sendo assim diminuídas as composições de tropas pagas, era imperioso o recurso aos corpos auxiliares sempre que as ameaças à ordem ganhavam maiores proporções. Incorria-se então na convocação dos agrupamentos de milícias e de ordenanças dos diversos pontos do território cearense. Era o funcionamento do que Victor Izecksohn qualificou como uma "organização militar dual", típica de nossa ordem colonial ${ }^{50}$.

Mas a convocação em larga escala de tropas auxiliares para lutar em batalhas violentas assumiria proporções inéditas durante as lutas da independência, o que veio a alterar as relações anteriormente estabelecidas entre oficiais e os soldados, sobretudo os das tropas auxiliares (ou seja, a maior parcela dos corpos armados). Fazer parte de tropas constituídas por grandes contingentes de soldados era, para muitos dos recrutados, uma experiência nova naqueles anos. Nesse sentido, em 1817, tão logo 
deslocados os soldados de linha de Fortaleza para tratarem da proteção de Aracati e outros pontos litorâneos, ordenou-se o engajamento de diversas tropas auxiliares provenientes de Acaraú, Granja e Sobral para seguirem em socorro ao exército governista então situado nas fronteiras com Rio Grande do Norte e Paraíba. Uma ordem expedida pelo governador Sampaio versa, nesse sentido, sobre a urgência com que o $1^{\circ}$ Batalhão de Infantaria de Granja deveria partir para a vila de Sobral e, em seguida, Campo Maior de Quixeramobim, "deixando as competentes ordens para que as outras companhias se vão também ali reunir". Detalhando as providências a serem tomadas, no ofício se lê:

Se as referidas companhias não estiverem completas as deverá VM. preencher, podendo elevar a cem o número de soldados de cada companhia, pedindo para este fim ao capitão mor os soldados de ordenanças que bem lhe parecer, o qual tem ordem para lhes entregar, o que contudo não deve retardar por maneira alguma a sua marcha para o Campo Maior.

A referência aponta para uma formação composta por destacamentos provenientes de origens divergentes, em que soldados regulares, treinados e fardados compõem uma menor parcela da expedição à qual confluiriam homens recentemente convocados, como era o perfil dos soldados de ordenanças, recrutados na ocasião entre a população pobre sertaneja. No sentido de se prevenir de qualquer eventual desavença entre os diferentes agrupamentos, a orientação em relação a esse destacamento plural era a de "conservar sempre a melhor harmonia, como pedem as atuais circunstâncias" ${ }^{51}$.

Em face à urgência de se obter pessoas aptas ao combate em grande número durante a intensificação dos conflitos, muitos índios, mamelucos, cabras, negros, inclusive escravos (os mesmos que os brancos se empenhavam por desarmar, em tempos ordinários) foram incorporados. Além do aumento dos contingentes nos corpos armados previamente existentes, novas tropas eram constituídas, como os "batalhões de pretos" criados por ordem de Tristão de Alencar durante as campanhas da Confederação do Equador.

É provável que a composição das tropas contasse com certo consentimento de indivíduos e grupos interessados em encontrar nas corporações algum meio de inserção social. Alguns trabalhos vêm destacando como a atuação de indígenas e afrodescendentes nas lutas da independência relacionavamse à defesa de aspectos importantes de suas condições de vida, visando encontrar no serviço das armas um instrumento para sua inserção na sociedade ${ }^{52}$. Por outro lado, as formas como se constituíram os agrupamentos atuantes nas campanhas enfocadas no presente artigo apontam para uma continuada resistência por parte das camadas subalternas, mesmo quando eram de fato recrutadas e engajadas nas batalhas.

A insubmissão esteve assim presente em diversas situações no cotidiano dessas tropas. Pela leitura de um ofício que tratava da promoção recebida pelo sargento mor José Agostinho Pinheiro, cuja atuação exemplar à frente das tropas de índios na expedição contrarrevolucionária em 1817 garantiu-lhe o cargo de novo comandante de ordenanças e diretor dos índios de Arronches, podemos perceber expectativas sobre a disciplina esperada por parte dos índios engajados. Elogiava-se, nesse sentido, o "grande gosto e bom arranjo e disciplina" com que o sargento mor "conteve os índios do seu comando, como ainda até agora não tinha visto nestes sertões". Expectativa semelhante sobre o mau comportamento costumeiro dos soldados estava subjacente no alerta dirigido ao capitão mor do Icó, dessa vez reprovado na conduta como responsável por aquela companhia armada. Tristão de Alencar considerava ter chegado aquela vila "ao auge de desgraças sem conta pelo desleixo com que as autoridades constituídas olham a profanação dos direitos do homem”, irregularidades essas atribuídas aos soldados ali concentrados. Alencar dizia-se convencido do total descontrole sobre a conduta dos praças, diante do que tratava de repreender o oficial responsável, orientando-lhe com veemência que "recobre ânimo, tenha vigor e cumpra o que deve com exatidão e logo terá soldados subordinados".

\footnotetext{
${ }^{51}$ Ofício de 19 de maio de 1817. Registro dos ofícios dirigidos aos militares desta capitania do Ceará, caixa 11, livro 37. Governo da Capitania: Correspondência expedida, Apec.

${ }^{52}$ Cf. SILVA, Luiz Geraldo. Op. Cit. COSTA, João Paulo Peixoto. Op. Cit. DANTAS, Mariana Albuquerque. Dimensões da participação política indígena na formação do Estado nacional brasileiro: revoltas em Pernambuco e Alagoas (1817-1848). 321 f. Tese (Doutorado em História), Programa de Pós-Graduação em História Social, Universidade Federal Fluminense, Niterói, 2015. 
Dirigindo-se ao capitão mor Pereira Filgueiras, na qualidade de governador das armas do Ceará, nos tempos da Confederação do Equador, ainda Tristão Gonçalves de Alencar clamava para que, com a força de sua reconhecida autoridade, Filgueiras pusesse freio ao que qualificava como "abusos" dos corpos militares da província que se "dilaceram como feras". Um exemplo apontado era a companhia de ordenanças de Sobral, exaltada no momento em que aquela vila se encontrava "na maior desordem", "caminhando tudo a uma subversão total e a uma anarquia horrorosa", segundo pensava o presidente Tristão de Alencar. Orientava então o sargento mor a "obstar com todas as forças" no sentido de "observar uma subordinação gradual e restrita em todos os indivíduos do corpo das ordenanças, desde o soldado até o chefe, prendendo e castigando severamente a todo e qualquer que desobedecer às ordens dos seus superiores" ${ }^{\prime \prime}$.

São expressivas as evidências que mostram como oficiais à frente dos corpos armados atuantes durante as lutas da independência viam com desconfiança o comportamento dos homens que o recrutamento em massa vinha incorporando como soldados, encarando-os como pessoas insubordinadas e somente capazes de servir nas tropas mediante intenso esforço por controle.

Da parte dos recrutáveis, as lutas da independência configuraram um tempo de resistência a um engajamento nas tropas que lhes pareciam ameaçar aspectos importantes de seus modos de vida. Durante a formação da expedição em auxílio aos ditos patriotas do Piauí, quando o recrutamento em massa atingiu seu auge, chegando a reunir um exército de cerca de oito mil homens à frente da vila de Caxias, no Maranhão, a insubordinação popular mostrou-se igualmente intensa. Nas vilas de Crato, Lavras, Icó e Jardim, "homens pardos e pretos que abundam naqueles lugares", como registrado em ofício de 6 de abril de 1823, temiam pela "perda do bem mais apreciável, qual a sua liberdade". Juravam resistir ao recrutamento pela força porque tinham a convicção de que "estão vendidos em Caxias e que a notificação para a marcha em socorro de Piaú é uma intriga que lhes queremos fazer para ali os embarcarmos" 54 .

A forma como se rebelavam os homens de cor passíveis ao recrutamento figurava aos líderes da expedição de 1823 como um quadro "o mais desgraçado; mil insubordinações, faces bem visíveis de uma anarquia e um total desprezo de nossa santa causa". Temia-se pelo surgimento de uma guerra civil. E, de fato, no dia 14 de abril, achavam-se reunidos na vila do Crato "mais de 2.000 cabras em armas e prontos a praticar as maiores hostilidades, tendo já perpetrado roubos e dispostos a instalar um governo a seu molde". Eram qualificados como "um partido furioso dos soldados de Nosso Senhor Jesus Cristo, como se chamam os cabras". E, quanto à hostilidade que demonstravam ter contra os agentes recrutadores, num episódio tomaram um recruta que se achava preso por ordem do governo e atacaram a casa de um oficial chamado José Dias, "deitando-se-lhe a primeira porta abaixo". Para conter os ataques, os moradores da casa atearam fogo em um barril de pólvora que, "levando a casa, não matou a um só dos malditos", como lamentaram Tristão de Alencar e Filgueiras em ofício ${ }^{55}$.

Nesse cenário de recorrente insubordinação por parte dos soldados, a aproximação das tropas representava um perigo para as populações das vilas, temerosas de ver aqueles homens armados avançarem sobre seus bens, sem que seus chefes pudessem exercer sobre eles um devido controle. O deslocamento em 1822 de José Pereira Filgueiras, "à testa de dois mil homens armados e apoiados dos chefes dos regimentos das vargens do Jaguaribe e Riacho do Sangue", fazia com que os habitantes de Aracati e de Fortaleza mobilizassem defesa, na intenção de manter a "tranquilidade dos cidadãos pacíficos, e ainda mesmo suas propriedades que se acham perigosamente expostas a uma força que não tem subordinação e inclinada para o mal". Receava-se inclusive que as mais destacadas autoridades da junta do governo viessem a ser insultadas pela plebe armada. Em 1824, quando a presença de soldados que haviam combatido pela expedição enviada para o Piauí parecia deixar a vila de Fortaleza numa espécie de estado de sítio, o presidente José da Costa Barros dirigiu-se ao governador das armas, ordenando a retirada dos soldados:

\footnotetext{
${ }^{53}$ Ofício de 4 de outubro de 1817. Registro dos ofícios dos capitães mores de distrito 1816-1817, caixa 11, livro 37. Governo da Capitania: Correspondência expedida, Apec. Grifos nossos. Ofícios de 12, 14 e 21 de maio de 1824. Apec. A Confederação do Equador no Ceará - manuscritos. Fortaleza: Arquivo Público do Estado do Ceará, 2004. vol. I, p. 72,81 e 108.

${ }^{54}$ Ofícios de 6 de abril de 1823. ARARIPE, Tristão de Alencar. Op. Cit., p. 261-262.

${ }^{55}$ Ofício de 20 de abril e 9 de maio de 1823. Ibidem, p. 307.
} 
Sendo do meu dever vigiar pela segurança dos indivíduos de toda a província e fazer com que se restitua a boa ordem a qual com tudo se acha perturbada por diferentes soldados milicianos, já da cidade, já de fora dela, cumpre que V. Ex. faça quanto antes retirar todos aqueles que não são moradores da cidade e proceder com vigilância sobre a tranquilidade da mesma, dando imediatamente as ordens necessárias ${ }^{56}$.

Arriscar a perda de controle sobre as tropas era o preço a ser pago pelas lideranças políticas, ao incorporar uma população pobre e mestiça, diuturnamente submetida à opressão e exploração por parte daquela mesma camada de homens brancos e privilegiados que agora os convocavam para a luta.

\section{A independência da plebe}

Os tempos da independência deixaram marcas profundas na sociedade cearense, perceptíveis por longos anos durante o século XIX, em todo seu espectro social. No que tange mais diretamente às suas camadas subalternas, as lutas da independência exerceram um papel que não deve ser subestimado, relativamente às experiências populares nos seus momentos mais decisivos. Neste artigo, buscou-se estudar essas experiências entre aqueles sujeitos que, de alguma maneira, foram engajados nas tropas (oficiais ou rebeldes) que se enfrentaram nas inúmeras batalhas que marcaram o período entre a Revolução de 1817 e o declínio da Confederação do Equador, em 1824. Encerrando os argumentos, apresentam-se em seguida algumas considerações sobre os desdobramentos sociais relacionados diretamente a esse período.

Os anos que se seguiram foram marcados por perseguições e punições. Tão logo restaurada a ordem na província, o governo imperial tratou de enviar ao Ceará, para exercer o cargo de comandante das armas, o tenente-coronel Conrado Jacob de Niemeyer, com a expressa missão de debelar todo foco de revolta que ainda houvesse. O rigor e a violência com os quais as forças governistas se voltaram contra a população sertaneja ficaram cravados na memória popular pela lembrança, viva até anos recentes, sobre a "guerra do Conrado", associada a um tempo de grandes perseguições, castigos físicos e recrutamentos forçados ${ }^{57}$.

A campanha repressiva foi sanguinária e intensa, perseguindo populações que se viram em 1825 envolvidas pelas dificuldades de um ano de seca e uma forte epidemia de varíola. A violência da repressão pode ser percebida por meio das orientações dadas ao tenente coronel Niemeyer pelo presidente da província. Taxando ex-combatentes como bandidos, ordenava a execução de castigos físicos para homens e mulheres: aos homens, mandava "passar a roda de pau" (colocar o indivíduo no centro de um grupo de soldados armados com cacetes), às mulheres, aplicar palmatórias à vista dos habitantes das vilas, "devendo todos os que levarem roda de pau ou palmatoadas serem soltos e mandados debaixo de boas vistas plantar ou aplicar-se ao serviço" ${ }^{58}$. O fuzilamento coletivo era outro recurso punitivo que deixava grandes impressões na população sobressaltada.

O recrutamento militar forçado talvez tenha sido o instrumento repressivo mais utilizado nesse tempo. Praticado de modo arbitrário, os desmandos dos recrutadores assumiram proporções escandalosas, a ponto da assembleia de deputados do Império discutir providências relativas ao assunto numa sessão de 1826. Um dos deputados declarou na ocasião:

A Província do Ceará se acha na maior desgraça possível, dois terços de seus habitantes estão foragidos e o estado de apuro e necessidade a que se acham reduzidos tem feito ladrões ratoneiros e salteadores, e o resto da Província se acha desamparada, sem poder sustentar a sua propriedade; há mortes diárias pelas estradas, o que nunca aconteceu no Brasil, e o recrutamento tem dado causa a isto no Ceará ${ }^{59}$.

\footnotetext{
${ }^{56}$ Ata da sessão extraordinária de 5 de novembro de 1823. Atas do Conselho Consultivo 1821-1822 / Junta do Governo Provisório da Província 1822-1823, caixa 9, livro 19. Governo da Capitania, Apec. Ofício de 19 de abril de 1824. Apec. A Confederação do Equador no Ceará - manuscritos. Fortaleza: Arquivo Público do Estado do Ceará, 2005. vol. II, p. 41.

${ }^{57}$ ASSUNÇÃO, Matthias Röhrig. A guerra dos Bem-te-vis: a Balaiada na memória oral, 2a ed. São Luiz: Edufma, 2008. p. 140.

${ }^{58}$ Ofício de 16 de abril de 1825. Apec. A Confederação do Equador no Ceará - manuscritos. Op. Cit., vol. II, p. $238-239$.

${ }^{59}$ BRASIL. Diário da Câmara dos Deputados a Assembleia Geral Legislativa do Império do Brasil 1826. Rio de Janeiro: Typographia Imperial e Nacional, 1826. p. 1.202. CÂNDIDO, Tyrone Apollo Pontes. Tempos de recrutamento: controle social e 
Os recrutados, em sua maioria, eram enviados para as frentes de batalha da guerra da Cisplatina, padecendo grandes sofrimentos durante o percurso. Famintos, esfarrapados (quando não completamente nus), eram embarcados sem a vacinação, tão necessária naquele tempo em que a varíola levava milhares à morte. Anos depois, uma matéria do jornal Cearense recordava aquele período, considerando a sustentação da guerra como um meio de o governo poder encaminhar para a morte os recrutados do Ceará e, desse modo, "enfraquecer as províncias do norte, como meio de acabar com o espírito de revolta e belicoso destas províncias" ${ }^{\circ}$.

Mas o "espírito de revolta e belicoso" não parece ter sido debelado, apesar da imensa repressão. Quase uma década de intensas batalhas fez com que as camadas inferiores dos sertões tivessem ganhado confiança em sua própria capacidade de sustentar protestos, mesmo após o declínio das disputas de poder entre as diferentes frações das elites. Rebeliões localizadas, de um perfil social mais popular, espalharam-se pelos sertões, como testemunhou o professor Manoel Ximenes de Aragão, em suas Memórias:

Já quase extintos os barulhos se achavam da parte dos patriotas e da do governo contra estes, quando menos se esperava, a população, lembrada dos acontecimentos desastrosos da Ilha de S. Domingos, cujos fatos eles não ignoravam e nem deixavam de falar deles, tratou de se juntar em grandes grupos e evadir todas as povoações e vilas em várias partes da província, principalmente no Cariri, na Serra do Pereiro, em Quixeramobim e na Serra

Grande com o desígnio de matar a patriotas ${ }^{61}$.

As Memórias de Manoel Ximenes de Aragão, seguindo uma prosa de contrainsurgência, apresentam evidências de como as camadas mais baixas dos sertões valiam-se dos tempos de revolta para sustentar uma luta cujo sentido estava dirigido contra o próprio domínio das minorias privilegiadas de proprietários brancos, aqueles mesmos que, até pouco tempo antes, encontravam-se à frente dos regimentos mobilizados. Nessas elites, Aragão enxergava homens de bem, uma gente de melhor qualidade, enquanto os pobres eram considerados como uma ralé ignorante, uma canalha desarrazoada e violenta. Era a forma como o professor Aragão enquadrou em suas memórias o medo pânico e a percepção de uma situação de suspensão de poderes que deixava a muitos sob o controle dos rebeldes, como se constata na passagem seguinte:

Neste desgraçado tempo, a gente melhor vivia cabisbaixa, aguentando tudo quanto a canalha lhe queria dizer, ia para onde a empurravam, pareciam todos enfermos, guardavam o mais profundo silêncio, estavam magros e pálidos porque todos os dias esperavam a sentença de sua morte e depois dela (o que há de mais sentir) ficarem suas famílias na posse daqueles brutos que, com a maior insolência, ao passar por qualquer porta ou janela onde estivesse alguma mulher branca, ousavam dizer - Vocês até agora tem parido brancos, para o ano parirão cabras! - Chegaria com efeito a esses extremos sua maldita premeditação se não fosse a intrepidez de alguns homens que opuseram alguma resistência, reprimindo os desígnios dessa canalha desenfreada antes que o governo tomasse conta do negócio, como tomou, que foi decerto quanto melhorou a sorte dos infelizes brancos que estavam a ponto de passar pela mesma cena da Ilha de S. Domingo ${ }^{62}$.

revoltas sertanejas no sertão do Ceará do século XIX. In: CÂNDIDO, Tyrone Apollo Pontes; NEVES, Frederico de Castro (org.). Capítulos de história social dos sertões. Fortaleza: Plebeu Gabinete de Leitura, 2017. p. 53-69.

${ }^{60}$ Cearense, 29 de novembro de 1849, Biblioteca Nacional.

${ }^{61}$ ARAGÃO, Manoel Ximenes de. Memórias do professor Manoel Ximenes de Aragão. Revista do Instituto do Ceará, ano XXVII, 1913. p. 62. Quando fala dos "acontecimentos desastrosos da Ilha de S. Domingos", Aragão refere-se à revolução iniciada na então colônia francesa em 1791, promovida pela população negra sob a liderança de Toussaint L'Overture e que resultou na independência e abolição da escravidão. A Revolução de São Domingos é considerada como a única insurreição de escravos vitoriosa entre a Antiguidade e os tempos modernos. Cf. JAMES, C. L. R. Os jacobinos negros: Toussaint L'Overture e a revolução de São Domingos. São Paulo: Boitempo Editorial, 2000.

${ }^{62}$ ARAGÃO. Op. cit. p. 71-72. 
A referência à presença do chamado haitianismo ${ }^{63}$, enquanto temor por parte das elites, porém também como assunto motivador das lutas plebeias nos sertões cearenses é um sinal de que aspirações características dos grupos de cativos foram compartilhadas por outros setores daquela população mestiça, formada também por brancos pobres e indígenas. Demonstra igualmente que a ideia de liberdade, apregoada como o projeto de emancipação política do país em relação à metrópole colonizadora, ganhava novos significados quando circulava entre as classes menos favorecidas da sociedade para as quais a opressão e o cativeiro tinham sentidos muito mais concretos.

É de se crer, portanto, que as difundidas experiências de militarização dos setores subalternos da sociedade, armados durante as lutas da independência, exerceram um papel importante na exaltação dos espíritos rebeldes nos anos que se seguiram. Desde então, a multiplicação de grupos armados pelos recantos sertanejos, não alcançados pelo controle por parte das instituições estatais, sustentou formas de resistência contra-hegemônicas que, em 1832, durante a chamada Revolta de Pinto Madeira, voltaria a ganhar contornos de rebelião por parte da plebe heterogênea. Mas essa já é uma outra história.

\section{Referências bibliográficas}

ALDEN, Dauril. O período final do Brasil colônia: 1750-1808. In: BETHEL, Leslie (org.). História da América Latina. São Paulo: Edusp, 1999. vol. II: América Latina colonial, p. 528-540.

APEC. A Confederação do Equador no Ceará - manuscritos. Fortaleza: Arquivo Público do Estado do Ceará, 2004. vol. I.

A Confederação do Equador no Ceará - manuscritos. Fortaleza: Arquivo Público do Estado do Ceará, 2005. vol. II.

ARAGÃO, Manoel Ximenes de. Memórias do professor Manoel Ximenes de Aragão. Revista do Instituto do Ceará, ano XXVII, 1913. p. 62.

ARARIPE, Tristão de Alencar. Expedição do Ceará em auxílio do Piauí e Maranhão. Revista do Instituto Histórico, Geográfico e Etnográfico do Brasil. Rio de Janeiro: Tipografia Universal de Laemmert, 1885. tomo XLVIII.

ARAÚJO, Maria do Carmo R. A participação do Ceará na Confederação do Equador. In: SOUZA, Simone (coord.) História do Ceará. Fortaleza: Universidade Federal do Ceará/Fundação Demócrito Rocha/ Stylus Comunicações, 1989. p. 139-148.

ASSUNÇÃO, Matthias Röhrig. A guerra dos Bem-te-vis: a Balaiada na memória oral, 2a ed. São Luiz: Edufma, 2008.

BERBEL, Márcia Regina. A nação como artefato: deputados do Brasil nas cortes portuguesas (1821-1822). São Paulo: Hucitec, 1999.

BERNARDES, Denis Antônio de Mendonça. A gente ínfima do povo e outras gentes na Confederação do Equador. In: DANTAS, Mônica Duarte (org.). Revoltas, motins, revoluções: homens livres pobres e libertos no Brasil do século XIX. São Paulo: Alameda, 2011. p. 131-166.

CÂNDIDO, Tyrone Apollo Pontes; NEVES, Frederico de Castro (org.). Capítulos de história social dos sertões. Fortaleza: Plebeu Gabinete de Leitura, 2017.

CARVALHO, Marcus Joaquim Maciel de. O outro lado da independência: quilombolas, negros e pardos em Pernambuco (1817-23). Luso-Brazilian Review, vol. 43, n. 1, 2006.

COSTA, João Paulo Peixoto. Na lei e na guerra: políticas indígenas e indigenistas no Ceará (1798-1845). 369 f. Tese (Doutorado em História), Programa de Pós-Graduação em História, Universidade de Campinas, Campinas, 2016.

DANTAS, Mariana Albuquerque. Dimensões da participação política indígena na formação do Estado nacional brasileiro: revoltas em Pernambuco e Alagoas (1817-1848). 321 f. Tese (Doutorado em História), Programa de Pós-Graduação em História Social, Universidade Federal Fluminense, Niterói, 2015.

FEIJÓ, João da Silva. Memória sobre a capitania do Ceará e outros trabalhos, ed. fac-similar. Fortaleza: Fundação Waldemar Alcântara, 1997.

FELIX, Keile Socorro Leite. "Espíritos inflamados": a construção do estado nacional brasileiro e os projetos

\footnotetext{
63 "Haitianismo" era a expressão com a qual se designava a circulação transatlântica de informações sobre a vitoriosa insurreição de escravos em São Domingos, motivando práticas rebeldes entre negros e provocando o medo de novas revoltas entre as elites brancas. Ver o artigo: SOARES, Carlos Eugênio; GOMES, Flávio dos Santos. Sedições, haitianismo e conexões no Brasil escravista: outras margens do Atlântico negro. Novos estudos Cebrap, n. 63, 2002. p. 131-144.
} 
políticos no Ceará (1817-1840). 231 f. Dissertação (Mestrado em História Social), Programa de PósGraduação em História, Universidade Federal do Ceará, Fortaleza, 2010.

GIRÃO, Raimundo. História econômica do Ceará, 2a ed. Fortaleza: Editora UFC, Casa José de Alencar, 2000.

GIRÃO, Valdelice Carneiro. As oficinas ou charqueadas no Ceará. Fortaleza: Secretaria de Cultura e Desporto, 1984.

GOMES, José Eudes. As milícias d’el rey: tropas militares e poder no Ceará setecentista. Rio de Janeiro: Fundação Getúlio Vargas Editora, 2010.

GUHA, Ranajit; SPIVAK, Gayatri Chakravorty. Selected subaltern studies. Oxford: Oxford University Press, 1988. p. v, vi.

IRFFI, Ana Sara Ribeiro Parente Cortez. O cabra do Cariri cearense: a invenção de um conceito oitocentista. 354 f. Tese (Doutorado em História Social), Programa de Pós-Graduação de História, Universidade Federal do Ceará, Fortaleza, 2015.

IZECKSOHN, Victor. Ordenanças, tropas de linha e auxiliares: mapeando os espaços militares luso-brasileiros. In: FRAGOSO, João; GOUVÊA, Maria de Fátima (org.). O Brasil colonial, 1720-1821. Rio de Janeiro: Civilização Brasileira, 2014. vol. 3, p. 483-521.

JAMES, C. L. R. Os jacobinos negros: Toussaint L'Overture e a revolução de São Domingos. São Paulo: Boitempo Editorial, 2000.

JANCSÓ, István (org.). Independência: história e historiografia. São Paulo: Hucitec, 2005.

JANCSÓ, István; PIMENTA, João Paulo Garrido. Peças de um mosaico (ou apontamentos para o estudo da emergência da identidade nacional brasileira). In: MOTA, Carlos Guilherme (org.). Viagem incompleta. A experiência brasileira (1500-2000). Formação: histórias, 2. ed. São Paulo: Senac, 2000. p. 127-175.

JUCÁ NETO, Clóvis Ramiro. Primórdios da urbanização no Ceará. Fortaleza: Edições UFC; Editora Banco do Nordeste do Brasil, 2012.

KOSTER, Henry. Viagens ao Nordeste do Brasil, 12a ed. Rio-São Paulo-Fortaleza: ABC Editora, 2003.

KRAAY, Hendrik. Identidade racial na política, Bahia, 1790-1840: o caso dos henriques. In: JANCSÓ, István. Brasil: a formação do estado e da nação. São Paulo: Hucitec, Ed. Unijuí, Fapesp, 2003.

LARA, Silvia Hunold. No jogo das cores: liberdade e racialização das relações sociais na América portuguesa setecentista. In: XAVIER, Regina Célia Lima (org.). Escravidão e liberdade: temas, problemas e perspectivas de análise. São Paulo: Alameda, 2010. p. 69-93.

MALERBA, Jurandir (org.). A Independência brasileira: novas dimensões. Rio de Janeiro: Fundação Getúlio Vargas Editora, 2006.

MARIANO, Serioja Rodrigues Cordeiro. Gente opulenta e boa linhagem: família, política e relações de poder na Paraíba (1817-1824). 286 f. Tese (Doutorado em História), Programa de Pós-Graduação em História, Universidade Federal de Pernambuco, Recife, 2005.

MELLO, Evaldo Cabral de. A outra Independência: o federalismo pernambucano de 1817 a 1824, $2^{\text {a }}$ ed. São Paulo: Editora 34, 2014.

MENEZES, Luís Barba Alardo de. Memória sobre a capitania do Ceará. Revista do Instituto Histórico e Geográfico Brasileiro, Rio de Janeiro, t. 34, n. 42, $1^{\text {a }}$ parte, p. 273, 1871.

MOTA, Carlos Guilherme. Nordeste 1817: estruturas e argumentos. São Paulo: Perspectiva, 1972.

PALACIOS, Guillermo. Campesinato e escravidão: uma proposta de periodização para a história dos cultivadores pobres livres no Nordeste oriental do Brasil: 1700-1875. In. WELCH, Clifford Andrew et al. Camponeses brasileiros: leituras e interpretações clássicas. São Paulo: Editora Unesp; Brasília, DF: Núcleo de Estudos Agrários e Desenvolvimento Rural, 2009. p. 145-180.

PAULET, Antônio José da Silva. Descrição geográfica abreviada da capitania do Ceará. Documentação primordial sobre a capitania autônoma do Ceará, $2^{\text {a }}$ ed. fac-similar de separatas da Revista do Instituto do Ceará. Fortaleza: Fundação Waldermar Alcântara, 1997.

PINHEIRO, Francisco José. Documentos para a história colonial, especialmente a indígena no Ceará (16901825). Fortaleza: Fundação Ana Luna, 2011.

REIS, João José. O jogo duro do dois de julho: o "partido negro" na independência da Bahia. In: REIS, J. J.; SILVA, E. Negociação e conflito: a resistência negra no Brasil escravista. São Paulo: Companhia das Letras, 1989. p. 79-98.

RIBEIRO, Gladys Sabina. O desejo da liberdade e a participação de homens livres pobres e "de cor" na Independência do Brasil. Caderno Cedes, Campinas, vol. 22, n. 58, p. 21-45, dez. 2002. 
SANTOS, João Brígido dos. Ceará (homens e fatos). Fortaleza: Edições Demócrito Rocha, 2001. (Col. Clássicos Cearenses)

Micellanea histórica ou coleção de diversos escriptos de J. Brígido, ed. fac-similar. Fortaleza: Fundação Waldemar Alcântara, 2009.

SILVA, Isabelle Braz Peixoto da. Vilas de índios no Ceará Grande. Dinâmicas locais sob o Diretório Pombalino. Campinas: Pontes Editores, 2005.

SILVA, Luiz Geraldo. Negros patriotas: raça e identidade social na formação do Estado nação (Pernambuco, 1770-1830). In: JANCSÓ, István. Brasil: a formação do estado e da nação. São Paulo: Hucitec, Ed. Unijuí, Fapesp, 2003.

SILVA, Luiz Geraldo; SOUZA, Fernando Prestes de. Negros apoyos. Milicianos afrodescendientes, transición política y cambio de estatus en la era de las independencias (capitanías de São Paulo y Pernambuco, Brasil, 1790-1830). Nuevo Mundo Mundos Nuevos, Débats 2014. Disponível em: <http://journals. openedition.org/nuevomundo/67529>. Acesso em: 6 de junho de 2018.

SOARES, Carlos Eugênio; GOMES, Flávio dos Santos. Sedições, haitianismo e conexões no Brasil escravista: outras margens do Atlântico negro. Novos estudos Cébrap, p. 131-144, n. 63, 2002.

STUDART, barão de. Datas e fatos para a história do Ceará. Fortaleza: Fundação Waldemar Alcântara, 2001.

STUDART FILHO, Carlos. A revolução de 1817 no Ceará. Revista do Instituto do Ceará, p. 5-99, ano LXXIV, 1960.

THEBERGE, Pedro. Esboço histórico sobre a província do Ceará, ed. fac-similar. Fortaleza: Fundação Waldemar Alcântara, 2001. tomo II.

VIEIRA Jr., Antônio Otaviano. Entre paredes e bacamarte: história da família no sertão (1780-1850). Fortaleza: Edições Demócrito Rocha/Hucitec, 2004.

XAVIER, Maico Oliveira. "Cabolullos são os brancos": dinâmicas das relações socioculturais dos índios do termo da vila Viçosa Real (século XIX). Fortaleza: Secult, 2012. p.148-194. 